\title{
Holiness on the Move: Relic Translations and the Affirmation of Authority on the Italian Edge of the Carolingian World
}

\author{
Francesco Veronese, Giulia Zornetta*
}

Between the eighth and ninth centuries many kings, dukes and counts in Carolingian Europe promoted the collection of relics in cathedrals and/or urban foundations both to centralize their power and to increase their prestige. Their ventures were part of a wider framework in which the mobility of the saints' bodies, which was strictly defined by the Carolingian authorities, put various political and social agents in a relationship, often competitive, with each other. This paper considers two cases of the translation of saints' bodies at the peripheries of the Carolingian Empire: the furta sacra of St Mark (from Alexandria, Egypt to Venice, 828) and St Bartholomew (from the island of Lipari to Benevento, 838-839). Both the hagiographical traditions narrate the theft and transport of the relics from the Islamic world to the Italian peninsula by boat. These two cases are also both related to a conscious and ambitious plan to strengthen local public authorities. The paper examines the underlying political strategies that led to the mobility of two of the most important relics in the Mediterranean context and the circulation of cultural models from the Carolingian worlds, which relocated the saints' bodies in order to redefine the political balance.

Keywords: translations of relics; public authorities; peripheries of the Carolingian Empire; Benevento; Venice

\section{Introduction}

In the ninth century, the mobility of saints' relics and the involvement of public authorities in the process of translation already had a long history. Since the mid-fourth century emperors had begun moving the relics of the apostles to Constantinople in order to shape it as a Christian capital. ${ }^{1}$ This pattern continued in various post-Roman communities, for example the politically driven relic translations that took place in the Lombard kingdom. In 725 King Liutprand moved St Augustine's body from Sardinia to his capital in Pavia and buried it in one of the most important churches of the capital city, San Pietro in Ciel d'Oro; later he endowed a monastic foundation there. ${ }^{2}$ During this period, the translation of St Augustine's relics was conceived as an important operation in terms of

\footnotetext{
* Correspondence details: Francesco Veronese, Giulia Zornetta, DiSSGeA - Dipartimento di Scienze Storiche, Geografiche e dell'Antichità, Università di Padova, via del Vescovado 30, 35141 Padova, Italy; email: francesco.veronese.3 @unipd.it; giulia.zornetta@unipd.it.

1 Cronnier, Les inventions, 333-354.

2 Historia Langobardorum, 6. 48, ed. Bethmann and Waitz, 181.
} 
its role in both sustaining and consolidating the king's public authority. ${ }^{3}$ The news of the translation spread as far as the Anglo-Saxon kingdoms, where Bede reported it in his De temporum ratione. ${ }^{4}$ As highlighted by Edoardo Manarini in this issue, relics and their installations in new locations were key assets in the affirmation of the great monasteries established in the eighth century by kings and aristocratic groups in the Lombard kingdom. ${ }^{5}$

Later in the eighth century, Charlemagne began regulating all matters concerning the cult of saints and their remains within his realm. ${ }^{6}$ Only those figures belonging to a distant past and renowned for their auctoritas passionum or vitae meritus were admitted. ${ }^{7}$ As a result, there was a significant increase in the production of hagiographical texts that served as the main means to prove a relic's antiquity. New texts were drafted and old ones rewritten. ${ }^{8}$

The relocation of relics was also regulated. The Council of Mainz (813) established that translations could only take place with the consent of the ruler and/or an assembly of bishops. ${ }^{9}$ A new genre of hagiography, translationes, developed in order to prove that relics had been moved according to Carolingian rules.

At the same time, accounts of illegal relocations, which openly broke the laws (both human and divine), also appeared. Einhard's Translatio Marcellini et Petri, written in 830-831, had a key role in the development of what Patrick Geary famously described as furta sacra. ${ }^{10}$ In Einhard's text, the choice to move relics was attributed to God and the saints themselves, whose authority was clearly higher than that of any worldly ruler. So, in Carolingian times both the practices and the narratives of the translation of relics were reshaped.

These choices and events appear to have also affected areas on the peripheries of the Carolingian world. In around the same years as Einhard's Translatio was written, possession of the evangelist Mark's body was claimed by the dukes of Venice, and in Benevento the Translatio sanctorum Ianuarii, Festi et Desiderii was written in the form of a furtum sacrum narrative. In both places all the aforementioned traditions - late Roman/Byzantine, Lombard, Frankish/Carolingian - helped remodel society and politics. Although the role of the Roman/Byzantine and Lombard traditions has long been acknowledged and highlighted by scholars, only recently has the exchange of practices and textual models between the Carolingian world and these regions been investigated in depth.

This paper compares how and evaluates why relics were translated in these contexts. By analysing how the elites and public authorities in Venice and Benevento exploited saints and relics to support their strategies, strengthen their social and political positions, and build their own legitimacy, the extent to which they were influenced by Carolingian rules becomes visible, illustrating the level to which these activities on the peripheries of the Carolingian world followed Carolingian patterns.

\footnotetext{
Di Muro, Uso politico delle reliquie.

De temporum ratione, 66, ed. Mommsen and Jones, 535.

Manarini, Translation of St Sylvester.

Riché, Carolingiens; Fouracre, Origins; Smith, Old saints, new cults.

Capitulare Francofurtense, 42, ed. Werminghoff, 170.

Goullet, Écriture et réécriture, 33-40; Gibson, Carolingian world.

Concilium Moguntinense, 51, ed. Werminghoff, 272.

Geary, Furta Sacra.
} 
Public Authority and Regional Competition: St Bartholomew and the Beneventan furta sacra According to hagiographic tradition, the translation of St Bartholomew from the island of Lipari took place in 838 at the instigation of Prince Sicard of Benevento (832-839) and thanks to some navigatores, probably the Amalfitans, who, unlike the Lombards, had a large fleet at their disposal. The relics were transported by ship to Salerno and in 839 they arrived in Benevento, where Sicard had a church built next to the cathedral in their honour, which, after the death of the prince, was completed by Ursus, the bishop of Benevento. ${ }^{11}$

Sicard's interest in St Bartholomew was aroused by the Islamic campaigns for the conquest of Sicily, which began in 827 with the landing in Mazara del Vallo and ended over a century later. ${ }^{12}$ Located just north of the island, the Aeolian archipelago had been sacked by the Aghlabids on at least two occasions and was in danger of being conquered by them..$^{13}$ The removal of the relics of St Bartholomew could therefore easily be justified as an attempt to save the disciple's precious body, a motivation that was in fact duly adopted by the hagiographic tradition. ${ }^{14}$ An initial account of the facts was probably written in Benevento after 839, but this first draft only exists now in the form of subsequent redrafts that were not written in Benevento itself. ${ }^{15}$ This also explains why the roles of Sicard and Bishop Ursus only emerge in a later narrative, the one written by a Beneventan monk, Martinus, in the mid-eleventh century. ${ }^{16}$

Hagiographic texts are, however, only one part of a larger whole that must be taken into consideration in order to understand the arrival of the body of St Bartholomew in Benevento. This translation must, in fact, be considered within the framework of the political designs of the Siconid dynasty, whose ambitions were not only focused on the Lombard territories, but on all of southern Italy.

After a conspiracy against Grimoald IV (806-817), Sico (817-832), the father of Sicard, assumed the title of prince thanks to the support of some members of the Beneventan elite. Both the chronicles and his funerary epitaph highlight his foreign origin and note that, unlike his predecessors, he was not part of the dynasty of the founder of the principality, Arechis (758-787) ${ }^{17}$ Lacking a vast family heritage and strong parental ties, it is likely that those who supported his seizure of power saw in him a leader who would be easy to influence. In reality, Sico proved to be highly skilled both in affirming his own political authority and in his relationship with the aristocracy, to which he tied himself through a shrewd marriage policy that saw his daughters as protagonists. ${ }^{18}$

Translatio, ed. Westerbergh, 10-12; Translatio S. Bartholomaei, ed. Borgia, 340-342.

Nef, Reinterpreting the Aghlabids.

3 Amari, Storia dei musulmani, 237-438; Kislinger, Storia di Lipari, 13-17.

Translatio S. Bartholomaei, ed. Borgia, 336-339.

Westerbergh, Anastasius, 49-52; Anderson, Historical Memory, 231-233.

Translatio S. Bartholomaei, ed. Borgia; Vuolo, Agiografia beneventana, 224-225.

17 Chronicon Salernitanum, 42, ed. Westerbergh, 42-43; Carmina varia, 2, ed. Dümmler, 649-651; Gesta episcoporum Neapolitanorum, 51, ed. Bethmann and Waitz, 428.

18 Chronicon Salernitanum, 55, ed. Westerbergh, 55; Thomas, Jeux lombards, 115-117; Zornetta, Italia meridionale longobarda, 161-163. 
The war against the Neapolitans helped consolidate the internal consensus around this prince. It diverted the heated internal competition of the first half of the ninth century towards the most traditional of external enemies, Naples, with which the Lombards had long fought over the fertile plain of Liburia. ${ }^{19}$

In 831 the Lombards besieged Naples, inflicting a crippling loss on Duke Stefano III (821-832), and leading to the imposition of an annual tribute on the Neapolitans. The local commercial market, which was the most important in the region, was also forced to use the Benevento currency. ${ }^{20}$ This was an opportunity to expand the economy of the Lombard hinterland, so much so as to suggest that commercial objectives were the foremost motivators of the military campaigns of the Siconids. ${ }^{21}$ This attempt, however, proved unrealistic, not only because it was short-lived, but also because the Beneventan coins contained a very modest quantity of gold compared to that of the Byzantine coins which circulated amongst traders in the Tyrrhenian region. ${ }^{22}$

These aggressive measures were also accompanied by the theft of the prestigious relics of St Januarius, which were brought by Sico to Benevento with great ceremony and entrusted to the custody of St Mary's cathedral. ${ }^{23}$

The Translatio sanctorum Ianuarii, Festi et Desiderii was written in Benevento shortly afterwards, and unsurprisingly does not explicitly indicate the theft of relics. The author pays little attention to the context of the war against the Neapolitans and justifies the translation of relics with one of the topoi of the hagiographic genre, that is the will of the saint to be found and be moved, in this case to return to his original episcopal see. ${ }^{24}$ According to tradition, in fact, Januarius was bishop of Benevento and he was martyred in Pozzuoli during the persecutions of Diocletian together with his companions, including Festus and Desiderius. As pointed out by Thomas Granier, both the narrative strategy of the hagiographic text and, above all, the silence of the chronicler Erchempert, a monk at the abbey of Monte Cassino who wrote his Ystoriola at the end of the ninth century, lead to the hypothesis that this theft struggled to find full acceptance amongst the Lombards. On the other hand, Neapolitan sources do not mention it because the abduction of the patron saint constituted a profound humiliation for the Tyrrhenian city, where the cult of Januarius continued almost undisturbed. ${ }^{25}$

It is precisely in this sense that Sico's decision to steal the relics and take them to Benevento must be interpreted as real spoils of war. ${ }^{26}$ However, this was not only a success on a military and religious level, but also in terms of the internal political balance.

3 Carmina varia, 2, ed. Dümmler, 650-651; Chronicon Salernitanum, 57, ed. Westerbergh, 58; Chronica monasterii Casinensis, 1.20, ed. Hoffmann, 66.

24 Translatio sanctorum Ianuarii, Festi et Desiderii, 888; Vuolo, Agiografia beneventana, 222-223; Geary, Furta Sacra, 108-118.

25 Granier, Miracle accompli; Granier, Lieux de mémoire, 63-102.

26 Granier, Conflitti, 36-39; Galdi, »Quam si urbem«, 226-228. 
Before the ninth century, St Mary's Cathedral had never been at the heart of elite Lombard patronage. It did not hold an important position either in terms of its own identity or in the context of urban devotions, which instead were concentrated in the numerous private churches and monasteries founded by the Lombard dukes and members of the Benevento elite. ${ }^{27}$

The translation of St Januarius enhanced the religious geography of the capital, endowing the episcopal see with an unprecedented importance and an increased level of visible representation of princely political authority. By entrusting these prestigious relics to the cathedral, Sico created a new urban devotional centre that competed with the illustrious St Sophia in Benevento. This female monastery was built by Arechis and modelled on St Salvator in Brescia, which had been founded by the Lombard king Desiderius and his wife Ansa before $757 .{ }^{28}$ Its prestige was inextricably linked to the birth of the southern principality of Benevento, which took place in 774 following the Carolingian conquest of the Lombard kingdom, from which the south of Italy was excluded. ${ }^{29}$ The church of St Sophia was also home to numerous relics, including those of St Mercury and the Twelve Brothers, whose bodies were moved to Benevento from some nearby towns. ${ }^{30}$ The complex founded by Arechis was therefore not limited to being the fulcrum of the prestige of the first prince, but also became the main centre of urban devotion.

When Sico came to power in 812, St Sophia was undoubtedly the richest and most important ecclesiastical institution in Benevento. It is therefore not strange that the new prince turned to another institution, the episcopate, to consolidate his prestige in the urban environment. From the first half of the ninth century, St Mary's Cathedral was recognized, alongside the palace and the princely court, as a place of representation of public authority and became the building - both religious and public - in which the Lombard princes exalted their link with the capital. Upon his death in 832, Sico chose to be buried in the cathedral's paradisus, as did the princes of the Radelchid dynasty. On the other hand, the tombs of Arechis and his descendants were located in the cathedral of Salerno, a city to which Arechis was particularly attached. ${ }^{31}$

During 833 Sicard resumed the conflict against Naples, which, in the meantime, had rebelled on several occasions against the previous agreement. In 836 he signed a new treaty with the city: the pactum Sicardi. ${ }^{32}$ However, this did not lead to a definitive pacification, so much so that the Neapolitans constant about-turns resulted in Sicard reformulating his project of expansion towards the Tyrrhenian coast. In order to bypass the commercial control of Naples, he tried to strengthen the economic role of Salerno by deporting Amalfitans to this city. ${ }^{33}$ Previously they had been invited to settle in Lombard territory enticed by generous

27 Fonseca, Particolarismo e organizzazione ecclesiastica; Rotili, Spazi monastici; Zornetta, Italia meridionale longobarda, 56-67; La Rocca, Élites, chiese e sepolture; Wood, Proprietary Church, 166-175.

28 Belting, Studien zum Beneventanischen Hof; Delogu, Mito di una città, 13-35.

29 Loré, Monasteri, re e duchi, 958-965; Zornetta, Monastero femminile.

30 Vuolo, Agiografia beneventana, 208-211; Galdi, Identità e pluralità, 99-101; Wood, Giovardi; Di Muro, Uso politico delle reliquie.

31 Chronicon Salernitanum, ed. Westerbergh, 24-26, 31-32; Delogu, Mito di una città, 38-69; Peduto, Arechi II a Salerno; Zornetta, Italia meridionale longobarda, 102-111.

32 Chronicon Salernitanum, 72-73, ed. Westerbergh, 70-72; Pactum Sicardi, ed. Martin; West, Communities and pacta, 384-389.

33 Chronicon Salernitanum, 74, ed. Westerbergh, 72-73. Di Muro, Economia e mercato, 82-86. 
donations, but only a small group accepted the proposal. ${ }^{34}$ Sicard then decided to act otherwise, and in 838 he sacked Amalfi and deported its inhabitants. On this occasion, the relics of St Trofimena, martyr of Minori, were also stolen, and they were once again entrusted to the cathedral of Benevento. ${ }^{35}$

The hagiographic work that traces this story is fundamental for understanding the relationship between Sicard and the Amalfitans. However, more than anything, it is the text that traces the events concerning the numerous movements involving the body of St Trofimena. Although its dating is debated, an initial version was certainly used by the anonymous author of the Chronicon Salernitanum and it therefore predates the end of the tenth century. ${ }^{36}$ The author was also not from the Lombard area, but was more likely of Amalfi-Minorese origin. ${ }^{37}$

Like the relics of St Januarius, those of St Trofimena also constituted the spoils of war. Once they reached Benevento, they made it possible to demonstrate and memorialize Sicard's recent military successes in the public and urban context of the cathedral.

These were not the only saints that came to the city during the principality of Sicard, as St Felicity and her seven sons were also added to the Benevento pantheon. Unlike the previous translations, this one does not seem to have been particularly publicized and the related hagiographic text only briefly mentions the involvement of the prince and the bishop..$^{38}$ Antonio Vuolo thus hypothesized that these relics had been purchased in Rome, perhaps through the organization led by the deacon Deusdona, known through Einhard's Translatio sancti Petri et Marcellini. ${ }^{39}$

As I have demonstrated above, the translations promoted by the Benevento princes concern how their public authority was represented. Their aim was to boost the prestige of Benevento as a religious centre and simultaneously promote its role as the capital of the principality. Although translations were a common feature of the Lombard world, both Arechis and the Siconids were probably following the model of the Lombard kings, i.e. Aistulf and Liutprand, who had accumulated numerous saints' bodies in the churches of Pavia and elsewhere.$^{40}$ What was unique in this case was the truly active role that the Benevento princes played in actually ensuring that these translations were carried out, which assigned an otherwise absent religious component to their public authority. Unlike what happened, for example, for the Carolingian kings, who took part in rites of consecration and unction by the bishops, the Lombard kings did not have a sacral dimension in any true sense. ${ }^{41}$ The participation of the princes of Benevento in the translation of relics was meant to compensate for this absence, thereby placing them in direct contact with the sacred.

34 Chronicon Salernitanum, 72*, ed. Westerbergh,71; Sangermano, Ducato di Amalfi, 294-295; Taviani-Carozzi, Principauté, 800-807.

35 Historia inventionis ac translationis, 235-236; Chronicon Salernitanum, 74, ed. Westerbergh, 72-73; Granier, Conflitti, 40-49.

36 Avallone, Historia S. Trophimenae, 763-767.

37 Oldoni, Agiografia longobarda, 603-614.

38 Passio et translatio Beneventum ss. Felicitatis, 18.

39 Translatio et miracula ss. Petri et Marcellini, ed. Waitz, 240; Geary, Furta Sacra, 44-49; Vuolo, Agiografia beneventana, n. 75, 221-222.

40 Tomea, Intorno a Santa Giulia, 34-46; Di Muro, Uso politico delle reliquie.

41 Gasparri, Kingship rituals. 
While Arechis merely centralized some cults that had already been established in the Beneventan area, the translations promoted by the Siconids not only encompassed a wider range but also had a more complex symbolic design, which included not only Lombard territory but also the whole of southern Italy..$^{42}$ Grafting the cults of Januarius and Trofimena onto Benevento was clearly an attempt to make the Lombard capital a religious reference point for the communities of the Tyrrhenian coast. While the Siconids' military campaigns certainly had an economic significance, albeit temporary and unrealistic, their thefts of relics suggest an attempt to widen the horizons of their project to a religious and political dimension.

It is in this context that the translation of St Bartholomew from Lipari must be read. To become the sacred reference point of all southern Italy, Benevento and its cathedral had to act as a counterpart to the ancient and prestigious tradition of the Neapolitan church. One of the ways to reach this goal was to enrich the city pantheon with a protector of the highest importance, such as a disciple of Christ. In fact, since the fifth century, the claim of an apostolic origin had been a key strategy for increasing the prestige and legitimacy of the episcopal church. ${ }^{43}$ Unlike what happened in Venice with St Mark, the cathedral of Benevento did not claim a tradition linked to the figure of Bartholomew, especially as he was active in the East rather than in the south of Italy, but limited itself to hosting the prestigious relics. However, the translation of St Bartholomew from Lipari should be interpreted both in terms of competition with the Tyrrhenian cities, Naples and Amalfi, and within the framework of the political designs of the Siconids throughout the whole south.

The arrival of the relics of St Bartholomew was certainly a success - but this was shortlived. In fact, in 839 Sicard was killed during a conspiracy hatched by the local aristocracy, and his ambitious political project came to an end. ${ }^{44}$ After his death, the Lombard principality was divided by factions and plagued by a violent conflict, which ended a decade later with the mediation of Emperor Louis II and Guy of Spoleto, and the birth of two distinct political bodies: the Principality of Benevento and the Principality of Salerno. ${ }^{45}$ In Benevento, the memory of the Siconids, especially of Sicard, underwent a kind of damnatio memoriae. Yet it was cultivated in Salerno, which became the capital of the principality led by Sicard's brother, Siconulf, in 849. In order to give prestige to the dynasty that formed the roots of this new Lombard principality, the Chronicon Salernitanum, a historiographic work written in Salerno at the end of the 1oth century, offers an overall positive image of the Siconids. However, while this is true for Sico and Siconulf in particular, Sicard is presented as a violent ruler, prey to irrational outbursts, and strongly influenced by the aristocracy. ${ }^{46}$

Although the relics of St Bartholomew were undoubtedly prestigious, after 849 they lost much of their political appeal in Benevento. In the latter half of the ninth century, the princes preferred to direct their devotion to St Januarius, probably because he was linked to a victorious ruler, Sico, and, above all, because he was directly linked to the identity of their 
town. The epitaphs of later rulers, who were also buried in St Mary's Cathedral, recall the special devotion of some of the members of the Radelchids to St Januarius. ${ }^{47}$ This dynasty ruled over Benevento until 900 and seems to have been particularly linked to the episcopal see, also in terms of how their political authority was portrayed. Adelchis (854-858) was the first prince to introduce the dedication to St Mary on coins minted in Benevento. ${ }^{48}$ One of the sons of Radelchis I (839-851), Aio, also obtained the office of bishop and tried to increase the prestige of the cathedral by relaunching the cult of the most important relics preserved in the cathedral: those of St Bartholomew. He requested help from Anastasius Bibliothecarius, a prominent figure of the Roman curia, who undertook a translation of Theodorus Studita's Sermo about the life of Bartholomew. ${ }^{49}$ In fact, as already mentioned, the hagiography of St Bartholomew had a rather complex tradition. There appears to have been a previous narrative relating to the relics being moved to Benevento, but there was also a short account of the text attached to Anastasius' translation. ${ }^{50}$

Again, however, the success of the renewal of the cult of Bartholomew seems to have been short-lived. At the end of the ninth century, the Principality of Benevento faced a series of setbacks. The Byzantines conquered much of what is now Puglia and Basilicata, causing the loss of an area rich in fiscal properties. ${ }^{51}$ The diocese of Benevento found itself divided into a territory where one part was subject to Lombard power and one to the Eastern Empire; this second part also included the prestigious sanctuary of San Michele al Gargano. On the other hand, Atenulf of Capua overthrew the Radelchids in 900 and the cathedral lost its role of supporting the political authority because the new dynasty remained mostly rooted in the city of Capua..$^{22}$ Unquestionably, from the 10th century onwards, the centre of gravity in southern Italy belonged to its maritime areas. Compared to the Tyrrhenian duchies and the Principality of Salerno, Benevento lost its political relevance and became peripheral.

[G. Z.]

\section{Competing Bodies, Chairs, Patriarchates: The Transfer of St Mark to Venice}

The Istoria Veneticorum, written by John the Deacon in Venice in the early eleventh century, recounts that in his last year of life, the duke Justinian Particiaco Sanctissimi Marci evangelistae corpus, de Alexandria a Veneticis allatum, recipere promeruit..$^{53}$ To install the relics in a worthy location, Justinian had a chapel built in the ducal palace, but he died before the work was accomplished, and the undertaking was completed by his brother and successor

Carmina varia, 12; 13, ed. Dümmler, 659; 660. Recently, on the Radelchids' epitaphs: Anderson, Historical Memory, 87-110.

48 Grierson and Blackburn, Medieval European Coinage, 1113-1114; 576.

49 Anastasii Bibliothecarii Epistolae, 18, ed. Perels and Laehr, 441-442.

50 Translatio, ed. Westerbergh, 8-17; Bonaccorsi, Sermo.

51 Loré, Curtis regia, 35-44.

52 Gasparri, Ducato e il principato, 130-134.

53 Istoria Veneticorum, 2. 39, ed. Berto, 118. 
John. The Istoria places the translation in $822 / 823$, the period in which Justinian ruled the duchy after the death of his father Agnellus, who had included his son in the administration of the government. According to the chronicler, Agnellus died in 822, but other sources indicate that Justinian was actually duke only between 828 and 829, raising uncertainty about the actual date of the translation.

The Istoria Veneticorum was compiled to exalt Venetian autonomy and the role played by Duke Peter II Orseolo (991-1009) as a peacemaker in conflicts between opposing family factions. ${ }^{54}$ John the Deacon's reconstruction of the history of the duchy was structured to project into the past the dichotomy between a group that supported an approach to western royal and imperial power and one that favoured the maintenance of privileged relations with Constantinople. While John the Deacon's account is not a neutral narrative, however, the dating of the translation of St Mark in 822/823 does not appear to be related to this strategy. He wrote about two centuries after those events, and probably made a miscalculation.

Placing the issues of the dating aside, the other aspects of the story are confirmed in previous sources. The translation was the subject of a hagiographical narrative, the Translatio sancti Marci, dated by Emanuela Colombi to the latter half of the tenth century. ${ }^{55}$ This text also refers to the duchy of Justinian, attributing to him the desire to build a chapel in the ducal palace, completed by his brother John. ${ }^{56}$ In the 860 s the monk Bernard, in the account of his pilgrimages, remembers that he went to Alexandria to pray at the body of St Mark, but that he was unable to do so, since the Venetians had stealthily appropriated it. ${ }^{57} \mathrm{~A}$ final confirmation came from Justinian's testament, dated hypothetically to 31st August 829, which has come down to us in incomplete late copies..$^{58}$ One of the lacunae concerns the passage in which the duke entrusted his wife Felicita with the task of arranging de corpus vero beati Mar[...], traditionally identified as that of St Mark.

Further evidence placing the translation between 828 and 829 comes from the analysis of the political context. Since the events that affected the duchy at the beginning of the ninth century have been the subject of precise reconstructions, including recent ones, I will limit myself to a few background details. ${ }^{59}$ Between 806 and 812 the Carolingians and the Byzantine emperors contended for control of the Upper Adriatic. In 804, during the plea of the Rižana, the aristocracies of Istria, a Carolingian territory that depended ecclesiastically on the Byzantine patriarchate of Grado, complained to the Carolingian authorities about the fiscal conditions imposed on them by $d u x$ John and Patriarch Fortunatus. ${ }^{60}$ The Annales regni Francorum $(A R F)$ for the year 806 opens by referring to a mission to Charlemagne by the duces Venetiae Obelerius / Willeri and Beatus, together with the dux and the bishop of

\footnotetext{
54 Pazienza, Archival documents; Provesi, Terre et la mer.

55 Colombi, »Translatio Marci evangelistae Venetias«, 76-79.

56 Translatio Marci evangelistae Venetias, 16.5-6, ed. Colombi,128-129.

57 Bernardi monachi Itinerarium, 6, ed. Ackermann, 117.

58 Ss. Ilario e Benedetto, 2, ed. Lanfranchi and Strina, 17-24. A new online edition by Annamaria Pazienza is available at saame.it/fonte/documenti-veneziani-venezia-4/, accessed on 16 February 2021.

59 Borri, Adriatico; Pazienza, Venice beyond Venice; West-Harling, Rome, Ravenna, and Venice, 89-100; Pazienza and Veronese, Pipino.

60 Borri, »Neighbors and relatives«; Pazienza, Archival documents.
} 
Zadar, that met in Thionville in northern France, following which Charlemagne issued an ordinatio de ducibus et populis tam Venetiae quam Dalmatiae that sanctioned the inclusion of the lagoons in the Carolingian domains and thus opened hostilities with Constantinople. ${ }^{61}$ From that year until 810 there were a series of military actions, followed by negotiations and truces between King Pippin of Italy and the commanders of the Byzantine fleets sent to the area ${ }^{62}$ In 810, after the death of his son Pippin, Charlemagne took over the negotiations. ${ }^{63}$ After exchanges of embassies, the matter was resolved in 812 with the Treaty of Aachen.${ }^{64}$ The $A R F$ links the event to an even more important achievement in Charlemagne's eyes, perhaps his underlying goal. On that occasion, the Byzantine ambassadors addressed him imperatorem eum et basileum appellantes. ${ }^{65}$ For the first time the Eastern emperors recognized the imperial power of Charlemagne, honouring him with the same title as they used for themselves. In short, the stakes were very high.

The Treaty of Aachen put an end to the disputes over the Venetian Duchy through diplomatic-military means, but the game moved to a new terrain. Between the Byzantine lagoons and the Carolingian hinterland there was a political and political-ecclesiastical border. The Byzantine lagoons depended on the patriarchate of Grado, while the churches in the hinterland were suffragans of the patriarchs of Aquileia. The separation between the two patriarchates occurred between the second half of the sixth century and the beginning of the seventh as a result of the schism of the Three Chapters and the Lombard conquest of much of the Italian peninsula. ${ }^{66}$ In the early ninth century this division of jurisdiction was delicately balanced but contested. To seek a remedy, on 6th June 827 a synod of the bishops of Aemilia, Liguria and Venetia met in Mantua. In the presence of two papal representatives and two of the emperors Louis and Lothar, they were all there to discuss the allocation of the ecclesiastical jurisdiction of Istria between Aquileia and Grado. ${ }^{67}$ The patriarch of Aquileia Maxentius presented a dossier consisting of libelli precum, sacrae litterae and other documentation in his possession.$^{68}$ He thus provided himself with a multiplicity of tools, starting with the selection of the place in the territory of the regnum, the audience and the participants. The documents presented by the deacon Tiberius in the name of the patriarch of Grado Venerius (who was absent) were deemed unreliable as they were nullius manu roborati. ${ }^{69}$ Maxentius' strategy paid off. The acknowledgment of the jurisdiction of Aquileia over the Istrian churches accompanied the reclassification of Grado to a plebs of Aquileia. ${ }^{70}$

$61 A R F$, a. 806, ed. Kurze, 120-121; Štih, Imperial politics, 65.

$62 A R F$, a. 806, 087, 809, 810, ed. Kurze, 122-130.

$63 A R F$, a 810, ed. Kurze, 133.

64 Ančić, Treaty of Aachen.

$65 A R F$, a. 812, ed. Kurze, 136.

66 Rando, Chiesa di frontiera, 13-14; Sotinel, Three Chapters.

67 Concilium Mantuanum, ed. Werminghoff; Azzara, Patriarchi contro; La Rocca and Veronese, Cultures of unanimity, 51-52.

68 Concilium Mantuanum, ed. Werminghoff, 585-586.

69 Concilium Mantuanum, ed. Werminghoff, 588.

70 Azzara, Concilio di Mantova. 
One of the arguments that Maxentius put forward in support of his position was the Marcian legend of Aquileia - the tradition that assigned the evangelization of northeast Italy and the foundation of the Christian community of Aquileia to St Mark. In Mantua, Maxentius began with a sort of calling card of the church of Aquileia, founded by Mark, the spiritual son of Peter, and the elegantissimus Hermachoras. ${ }^{71}$ The Aquileian church was therefore a direct derivation (discipula, peculiaris, vicaria) of the Roman one. Hermachoras, Mark's first successor, was invoked again towards the end of the proceedings. ${ }^{72}$ While he resided in Aquileia, Mark, who was eager to see his master, took to Rome the elegans vir Hermachora, ab omni electus clero et populo and consecrated bishop by Peter in person. Peter, Mark and Hermachoras were thus established as the founders of the relationship between the churches of Aquileia and Rome. Hermachoras, who had been invested with religious authority by Peter, had previously been elected bishop by the people and clergy of Aquileia, in compliance with canonical procedures. This was in contrast to the election of Candidianus, the first patriarch of Grado, which the council described as taking place contra canonum statuta et sanctorum patrum decreta. ${ }^{73}$ The aim was to discredit the patriarchal succession of Grado by opposing it to the legitimate and apostolic tradition supposedly held by the Church of Aquileia.

The first mention of the Marcian legend appears in the Liber de episcopis Mettensibus written by Paul the Deacon in the $780{ }^{.74}{ }^{74}$ Its origins, however, have been traced back to the schism of the Three Chapters. According to Pier Franco Beatrice, Gregory the Great conceived the legend to affirm the authority of Rome over the schismatic patriarchate of Aquileia, presenting its origins as the result of an initiative promoted by Peter. ${ }^{75}$ In any case, in the 830 s the legend appeared sufficiently authoritative to be exploited to establish the superior metropolitan dignity of Aquileia over Grado. The assembly in Mantua marked a significant turning point in how the legend was portrayed. ${ }^{76}$ References to St Mark re-emerge in several places in the council's acts. Maxentius's speech included a quote from Paul the Deacon's Historia Langobardorum, which was dedicated to the flight of his predecessor Paul to Grado in 568/569. ${ }^{77}$ The text was, however, modified in order to underline the temporary and emergency nature of the transfer of the see and the illegitimacy of the election of Candidianus. The privileged relationship between St Mark and Aquileia was further strengthened with a reference to the relics of the saint. Paul the Deacon recounted that at the time of his flight, Paul took with him the treasure of his Church. ${ }^{78}$ The synodal acts specify that the chairs (sedes) of Mark and Hermachoras were also part of that treasure. ${ }^{79}$ Their possession

Concilium Mantuanum, ed. Werminghoff, 585.

Concilium Mantuanum, ed. Werminghoff, 588-589.

Concilium Mantuanum, ed. Werminghoff, 586.

4 Liber de episcopis, ed. Santarossa, 129.

75 Beatrice, Hermagorica novitas.

76 Veronese, Saint Marc, 300-301.

77 Concilium Mantuanum, ed. Werminghoff, 585-586.

78 Historia Langobardorum, 2. 10, ed. Bethmann and Waitz, 78.

79 Concilium Mantuanum, ed. Werminghoff, 585 . 
by the Church of Aquileia demonstrated the reliability of the Marcian legend, and therefore the antiquity and prestige of the patriarchate. The Marcian tradition was then detailed in the final part of the acts, in which the foundation of Grado, a simple fortification (munitio), was traced back to the Aquileian patriarchs. ${ }^{80}$

The dossier assembled by Maxentius was effective because it was not addressed to the local communities of northeastern Italy but rather to a Carolingian audience, made up of the bishops gathered there and the envoys of the pope and the emperors; and it was done through strictly Carolingian means. The resources of the past, such as the Marcian legend and the Historia Langobardorum, were placed at the service of present needs, through pathways also attested, for example, by the $A R F{ }^{81}$ The libelli precum were key to defining a common Christian culture in the Carolingian Empire. ${ }^{82}$ The memory and the relics of St Mark were an integral part of this strategy, and served as the means for establishing the antiquity - and therefore the admissibility in the eyes of the Carolingian authorities - of a cult through its hagiography. Several scholars have identified an element of the dossier in the Passio Hermachorae et Fortunati, whose prologue, which was added to the original text on the cusp of the eighth and ninth centuries, is dedicated to Mark's mission in Aquileia. ${ }^{83}$ The presence of the two papal delegates at the assembly in Mantua strengthens this hypothesis: the prologue of the Passio highlights the link between Peter and Mark and the derivation of the Church of Aquileia from the Roman Church. ${ }^{84}$ Its inclusion among the sacrae litterae of Aquileia thus benefitted Maxentius's cause.

Despite the peremptory nature of the decisions taken in Mantua, the question was not resolved. The Aquileian offensive triggered reactions from various actors. In Grado they took the shape of written responses. In the Carmen de Aquilegia numquam restauranda, Maxentius, who was defined as veneficus and venenosus, was accused of having tried to trick three emperors - Charlemagne, Louis the Pious, and Lothar - in order to extend his ecclesiastical dominion over totam Dalmatiam..$^{85}$ The drafting of the Passio Helari et Tatiani, which was interpreted as a polemical response to the Passio of Hermachoras and Fortunatus, has been traced back to a similar initiative by Grado. ${ }^{86}$

Above all, Maxentius' reinterpretation of the past was revived and rejected by his opponents. In her edition of the Translatio Sancti Marci, Emanuela Colombi stressed its two-part structure: a historical prologue, dedicated to the origins of the Grado patriarchy, and the actual narrative of the translation. ${ }^{87}$ The first part is presented as "a sort of rreasoned - and manipulated - anthology point-by-point response to the arguments that had decreed the Aquileian victory in $827 .{ }^{88}$

80 Concilium Mantuanum, ed. Werminghoff, 588-589.

81 McKitterick, Charlemagne, 31-54; Reimitz, History, 293-334.

82 Pilsworth, Vile Scraps, 178-180; Phelan, Formation, 249-252.

83 Picard, Souvenir des évêques, 414-415; Vocino, Under the aegis, 32-33.

84 Passio Hermachorae, ed. Chiesa, 171-176.

85 Carmen de Aquilegia numquam restauranda, ed. Dümmler; Gasparri, Formation, 40-42.

86 Passio Helari et Tatiani, ed. Cerno. For its attribution to Grado, Vocino, Saints, 288-291; for a different view, Cerno, Aquileian patriarchate's title.

87 Colombi, »Translatio Marci evangelistae Venetias«, 76-81.

88 Colombi, »Translatio Marci evangelistae Venetias«, 76; Colombi, Alcune riflessioni. 
A comparison between the acts of Mantua and the prologue of the Translatio offers evidence for this interpretation. Both texts drew from the Historia Langobardorum, but in taking up the same passages, they collated and reworked them in opposite ways. In the prologue of the Translatio, the flight of Paul to Grado was placed within a broader historical context, defined by the Gothic wars and the Lombard invasion of the peninsula, in order to reconstruct the motivations behind it. ${ }^{89}$ The change of the episcopal see was thus justified within a context of political and ecclesiastical transformations. The effort to establish the definitive character of this change, in contrast to what was stated in Mantua, was supported by a reference, absent in Paul the Deacon, to the council convened at Grado in 579, during which the bishops gathered there raised Grado to totius Venetiae metropolis..$^{90}$ The provision was also ratified ex consensu beatissimi papae Pelagii. ${ }^{11}$ In other words, more than two centuries before the synod of Mantua disavowed the flight of Paul as a displacement of the patriarchal see, another synod, equally certified by the papal authority, had instead established that displacement as a definitive act.

The real trump card of Maxentius, as the author of the prologue well knew, was, however, the Marcian legend. Rather than attempting to discredit it, he cleverly reinterpreted the legend to support his rationale. Some of his reinterpretations of the narrative of Paul the Deacon concern the details of the transfer of the see that call into question the relics of Mark and Hermachoras. The text of the Historia had already been interpolated in the acts of Mantua, attributing to the patriarch the saving of the chairs of the two saints. The author of the prologue interpolated this interpolation, stating that it was not the chairs of Mark and Hermachoras that were being moved, but rather the bodies of the martyrs of Aquileia - including that of Hermachoras. ${ }^{92}$ In his version the chair of Mark was sent to the patriarchs only at the beginning of the seventh century by the emperor Heraclius to seal the change of see. ${ }^{93}$ The two texts therefore attributed this relic with very different functions. In the acts it was placed at the foundation of the Aquileian episcopal tradition, not interrupted by its temporary sojourn in Grado. In the prologue of the Translatio, Mark's chair served instead to renew the link between the saint and the patriarchate after a definitive transfer endorsed both by the pope and by the Byzantine emperors. The author of the Translatio echoed the importance attributed by the acts to the relics of Mark and Hermachoras, taking up the challenge and exploiting them to his advantage. In his account, after Paul's escape, the bond between the true patriarchs (of Grado) and St Mark was strengthened through the acquisition of a new relic; in other words, only thanks to the relocation of the see did Mark's chair come to Italy.

Maxentius' claims entailed a complex reworking of the past reinforced by references to ancient and prestigious relics. The writer of the prologue of the Translatio exploited the same arguments, but with a very different interpretation: he agreed to be judged by norms established by the Carolingians. However, even this was not considered sufficient. In addition to the textual strategies expressed in the prologue of the Translatio, the Venetian duchy

89 Translatio Marci evangelistae Venetias, ed. Colombi, 112-116.

90 Translatio Marci evangelistae Venetias, ed. Colombi, 115-116.

91 Translatio Marci evangelistae Venetias, ed. Colombi, 115-116.

92 Translatio Marci evangelistae Venetias, ed. Colombi, 115.

93 Translatio Marci evangelistae Venetias, ed. Colombi, 116. 
went even further in its investment in relics of Mark by procuring his body. ${ }^{94}$ The translation seems to have taken place between 827 and 829, in line with the needs and strategies of Venice and Grado in the aftermath of the pronouncements of the Mantuan synod. To safeguard the duchy's ecclesiastical and political autonomy, it reacted by resorting to a material shift of holiness. The translation allowed the dukes to enter into disputes that concerned them a great deal but from which they had been excluded when, after the Treaty of Aachen, the level of international relations was replaced by that of hierarchies between dioceses. The acquisition of new Marcian relics served to strengthen the apostolic identity of the patriarchate, placing it on an equal footing with Aquileia. In this way their owners, the dukes, carved out an unprecedented role in the dispute between Aquileia and Grado. The prologue of the Translatio and the translation belonged to the same context of political-ecclesiastical competition and appear to be united by their adherence to discourses and tools developed in a Carolingian context, which was linked to the cult of saints and relics. By agreeing to play according to the rules set by others, Venice and Grado astutely managed to preserve their ecclesiastical autonomy against Aquileian attempts to increase its influence.

\section{[F. V.]}

\section{Conclusions}

In exploiting the translation of relics, the dukes of Venice and the princes of Benevento proved to be well informed about what was happening in the nearby Carolingian world and how to leverage new patterns of hagiographic promotion to their benefit. The translations discussed here occurred at a time when the relics of the saints began to circulate with renewed intensity throughout the Frankish Empire, taking on a new role within the machinery of political and social competition. For example, the $A R F$ for 826 reported that Hilduin commissioned the translation of the body of St Sebastian to Soissons, and for 827, that Einhard did the same for Marcellinus and Peter to Seligenstadt. ${ }^{95}$ Both elevated the status of the sanctuaries that hosted them to key places in the political and religious life of the empire. In 833 Louis the Pious was subjected to public penance in Soissons, in the basilica of St Mary, where the body Sebastiani praestantissimi martyris rested. ${ }^{96}$ In his letters Einhard presented himself as the spokesman for his martyrs, who were assigned with the role of protecting the peace and stability of the empire. ${ }^{97}$

Given that the councils and capitularies had forbidden the raising of new figures to veneration, the acquisition of relics of established or acknowledged saints became the only way to make use of sainthood - a sainthood as far removed in time and space as possible - as an instrument to legitimize one's strategies or claims. The translations and their narrations - the translationes - are an indication of the position of those who performed them towards the Carolingian power and the rules it imposed on the cult of the saints. The very fact of resorting to the translation of relics underlined an adherence to the principles that guided this legislation, because it implied the exploitation of already existing saints rather than the creation of new holy figures. This is also true in the case

94 Geary, Furta Sacra, 88-94.

$95 A R F$, a. 826; a. 827 ed. Kurze, 171-172; 174.

96 Relatio Compendiensis, ed. Booker, 15.

97 Sot, Service de l'empire. 
of furta sacra, in which the violation of these rules by carrying out translations without authorization (and subsequently legitimizing the translations by narrating them) served to reinforce the Carolingian regulatory framework by the very fact of breaking it. ${ }^{98}$ Both the legitimate translations and the thefts of relics (and the respective narratives), as they were configured in the Carolingian world, were products of the "Carolingian attempt to regulate the cult of saints «, 99 and therefore indicators of the level of success of this attempt.

Venice and Benevento were political entities on the peripheries of the empire, or rather, several empires. Through their proximity to and reliance on Carolingian political power, they accessed and astutely mimicked the strategies that were becoming the norm in the Carolingian sphere. ${ }^{100}$ They did so by turning to prestigious saints from the past, for whom the auctoritas passionum and the vitae meritus were documented through hagiography beyond any reasonable doubt, and by welcoming their material remains. The choice was not necessarily entirely spontaneous: in the Venetian case of St Mark, his memory and his relics were first recalled by Maxentius of Aquileia. In the case of Benevento, the choice and the initiative were all down to the Siconids. However, both cases appear to reflect not only the existence of but also the adherence to a common language, the one developed in (and imported from) the Carolingian world, relating to the use of sainthood and relics to support political competitions. In Venice and Grado, in the need to respond to the patriarch of Aquileia with his own (and totally Carolingian) means and arguments, this language was combined with reinterpretations of the past and its sources. In Benevento, on the other hand, the Siconids appropriated the new concept of a furtum sacrum to give strength to their political ambitions, on the one hand in competition with the Tyrrhenian cities of Byzantine tradition and on the other in the representation of their political authority in the framework of their capital city.

Thus, neither the dukes of Venice nor the princes of Benevento limited themselves to absorbing the Carolingian language of sainthood and its instructions for use, but rather craftily re-employed it to pursue their own purposes, sometimes diverging from the interests of the Carolingians. The Venetian dukes used it to avoid being subjected to a politically very close figure to the Carolingians, i.e. Maxentius. The Siconids did so in an attempt to create a regional domination on the southern borders of the empire. In short, both showed that they understood the political value of discourses and textual tools developed in the Carolingian world, but also that they knew how to take advantage in multiform and above all autonomous ways.

It was not a one-way process. During the abbacy of Erlebald (822-838) in Reichenau, a monastery on Lake Constance awarded with royal protection, an anonymous monk recounted in the Commemoratio brevis de miraculis Genesii that, before arriving in the Alamannian monastery of Schienen, a relic of the martyr Genesius passed through Venice and was acquired through the mediation of Venetian negotiatores ${ }^{101}$ About half a century later, another monk from Reichenau reported in the Translatio Ianuarii that Januarius's relics had arrived in the monastery at the time of Louis II. The image of Venice and southern Italy as areas characterized by the translation of relics was therefore accepted in the Carolingian world and integrated into its narratives.

98 Veronese, Rispetto delle leggi.

99 The reference here is to Fouracre, Origins.

100 Smith, Old saints, new cults; Vocino, Traslazioni.

101 Commemoratio brevis, ed. Wattenbach, 9.

medieval worlds $\bullet$ No. $13 \cdot 2021 \cdot 54-75$ 


\section{Acknowledgements}

This article has been published within the framework of the Mobility \& Humanities project of the University of Padua's Department of Historical and Geographical Sciences and the Ancient World (DiSSGeA). The Mobility \& Humanities project is funded as a Project of Excellence (2018-2022) by the Italian Ministry of Education, University and Research (MIUR). The authors would like to thank Edward Schoolman for reading and improving the previous version of this text. 


\title{
References
}

\author{
Abbreviations \\ AASS = Acta Sanctorum \\ $\mathrm{ARF}=$ Annales regni Francorum \\ BHL = Bibliotheca Hagiographica Latina, 2 vols. (Brussels, 1898-1899) \\ CCSL = Corpus Christianorum, Series Latina \\ CISAM = Centro italiano di studi sull'alto medioevo \\ MGH = Monumenta Germaniae Historica \\ $\mathrm{EE}=$ Epistolae \\ $\mathrm{SS}=$ Scriptores
}

Amari, Michele, Storia dei musulmani di Sicilia (Catania, 1933).

Anastasii Bibliothecarii Epistolae, ed. Ernst Perels and Gerhard Laehr, MGH EE. Karolini aevi 5 (Berlin, 1928) 395-442.

Ančić, Mladen, The treaty of Aachen: How many empires?, in: Mladen Ančić, Jonathan Shepard and Trpimir Vedriš (eds.), Imperial Spheres in the Adriatic: Byzantium, the Carolingians and the Treaty of Aachen (812) (London, 2018) 25-42.

Anderson, Julie Michelle, Historical Memory, Authority, and the Written Word: A Study of the Documentary and Literary Culture at the Early Medieval Court of Benevento, 70o900 CE, Unpublished $\mathrm{PhD}$ thesis (University of Toronto, 2017).

Annales regni Francorum, ed. Friedrich Kurze, MGH SS rerum Germanicarum 6 (Hanover, 1895).

Arslan, Ermanno, Monetazione di età longobarda nel Mezzogiorno, in: Giuseppe Roma (ed.), I Longobardi del Sud (Rome, 2010) 85-98.

Avallone, Riccardo, La Historia S. Trophimenae e il Chronicon Salernitanum, Critica letteraria 69/4 (1990) 757-774.

Azzara, Claudio, Il concilio di Mantova del 6 giugno 827, in: Giancarlo Andenna and Gian Pietro Brogiolo (eds.), Le origini della diocesi di Mantova e le sedi episcopali dell'Italia settentrionale (IV-XI secolo) (Trieste, 2006) 61-72.

Azzara, Claudio, Patriarchi contro: Aquileia, Grado e il concilio di Mantova dell'827, in: Bruno Figliuolo, Rosalba Di Meglio and Antonella Ambrosio (eds.), Ingenita curiositas: Studi sull'Italia medievale per Giovanni Vitolo (Battipaglia, 2018) 287-298.

Beatrice, Pier Franco, Hermagorica novitas: La testimonianza di Colombano sullo scisma dei tre capitoli, in: Sergio Tavano, Giuseppe Bergamini and Silvano Cavazza (eds.), Aquileia e il suo patriarcato: Atti del Convegno Internazionale di Studio (Udine 21-23 ottobre 1999) (Udine, 2000) 75-93.

Bedae De temporum ratione liber, ed. Theodor Mommsen and Charles W. Jones, CCSL 123B (Turnhout, 1977).

Belting, Hans, Studien zum Beneventanischen Hof im 8. Jahrhundert, Dumbarton Oaks Papers 16 (1962) 143-193.

Bonaccorsi, Ilaria, Il Sermo de sancto Bartholomeo apostolo, interprete Anastasio Bibliothecario, in: Krassimir Stantchev and Stefano Parenti (eds.), Liturgia e agiografia tra Roma e Costantinopoli (Grottaferrata, 2007) 11-23.

Borri, Francesco, L’Adriatico tra Bizantini, Longobardi e Franchi. Dalla conquista di Ravenna alla pace di Aquisgrana (751-812), Bullettino dell'Istituto Storico Italiano per il Medio Evo 112 (2010) 1-56. 
Borri, Francesco, »Neighbors and relatives«: The plea of Rižana as a source for northern Adriatic elites, Mediterranean Studies 17 (2008) 1-26.

Capitulare Francofurtense, ed. Albert Werminghoff, MGH Concilia 2/1 (Hanover, 1906) 165-171.

Carmen de Aquilegia numquam restauranda, ed. Ernst Dümmler, MGH Poetae Latini aevi Carolini 2 (Berlin, 1884) 150-153.

Carmina varia, ed. Ernst Dümmler, MGH Poetae Latini aevi Carolini 2 (Berlin, 1884) 649-686.

Cerno, Marianna, Holding the Aquileian patriarchate's title: The key role of local early-ninthcentury hagiography, in: Mladen Ančić, Jonathan Shepard and Trpimir Vedriš (eds.), Imperial Spheres in the Adriatic: Byzantium, the Carolingians and the Treaty of Aachen (812) (London, 2018) 140-151.

Chronica monasterii Casinensis, ed. Hartmut Hoffmann, MGH SS 34 (Hanover, 1980).

Chronicon Salernitanum. A Critical Edition with Studies on Literary and Historical Sources and on Language, ed. Ulla Westerbergh (Lund, 1956).

Colombi, Emanuela, Alcune riflessioni sull'Istoria Veneticorum del diacono Giovanni e il prologo della Translatio Marci evangelistae (BHL 5283-5284), Studi veneziani n.s. 64 (2011) 15-54.

Colombi, Emanuela, "Translatio Marci evangelistae Venetias« (BHL 5283-5284), Hagiographica 17 (2010) 73-129.

Commemoratio brevis de miraculis sancti Genesii martyris Christi, ed. Wilhelm Wattenbach, Die Übertragung der Reliquien des h. Genesius nach Schienen, Zeitschrift für die Geschichte des Oberrheins 24 (1872) 1-21: 8-21.

Concilium Mantuanum, ed. Albert Werminghoff, MGH Concilia 2/2 (Hannover, 1908) 583589.

Delogu, Paolo, Mito di una città meridionale (Salerno, secoli VIII-XI) (Naples, 1977).

Di Muro, Alessandro, Economia e mercato nel Mezzogiorno longobardo (secc. VIII-IX) (Salerno, 2009).

Di Muro, Alessandro, Uso politico delle reliquie e modelli di regalità longobarda da Liutprando a Sicone di Benevento, Mélanges de l'École française de Rome - Moyen Âge 132/2 (2020). Accessed on 16 February 2021: journals.openedition.org/mefrm/8193.

Erchemperti Historia Langobardorum Beneventanorum, ed. Ludwig Bethmann and Georg Waitz, MGH SS rerum Langobardicarum et Italicarum (Hanover, 1878) 231-264.

Fonseca, Cosimo Damiano, Particolarismo e organizzazione ecclesiastica delle campagne nell'Alto Medioevo nell'Italia meridionale, in: Cristianizzazione ed organizzazione ecclesiastica delle campagne nell'alto Medioevo: espansione e resistenze. Settimane di studio del Centro italiano di studi sull'alto medioevo 28 (Spoleto, 1981) 1163-1200.

Fouracre, Paul, The origins of the Carolingian attempt to regulate the Cult of Saints, in: James Howard-Johnston and Paul Anthony Hayward (eds.), The Cult of Saints in Late Antiquity and the Middle Ages: Essays on the Contribution of Peter Brown (Oxford, 1999) 143-165.

Galdi, Amalia, Identità e pluralità nella Benevento longobarda: Poteri e culti dei santi, in: Errico Cuozzo and Mario Iadanza (eds.), Il ducato e principato di Benevento: aspetti e problemi (secoli VI-XI) (Benevento, 2014) 93-110.

Galdi, Amalia, "Quam si urbem illam suae subdiderit«: La traslazione delle reliquie di san Gennaro a Benevento tra istanze politiche, agiografia e devozione, in: Gennaro Luongo (ed.), San Gennaro nel XVII centenario del martirio (Naples, 2007) 223-242.

Gasparri, Stefano, Il ducato e il principato di Benevento, in: Giuseppe Galasso and Rosario Romeo (eds.), Storia del Mezzogiorno 2/1: Il Medioevo (Naples, 1988) 83-146. 
Gasparri, Stefano, The formation of an early medieval community: Venice between provincial and urban identity, in: Veronica West-Harling (ed.), Three Empires, Three Cities: Identity, Material Culture and Legitimacy in Venice, Ravenna and Rome, 750-1000 (Turnhout, 2015) 35-50.

Gasparri, Stefano, Kingship rituals in Lombard Italy, in: Frans Theuws and Janet Nelson (eds.), Rituals of Power: From Late Antiquity to the Early Middle Ages (Leiden, 2000) 95-114.

Geary, Patrick, Furta Sacra: Thefts of Relics in the Central Middle Ages (Princeton, 1991).

Gesta episcoporum Neapolitanorum, ed. Ludwig Bethmann and Georg Waitz, MGH SS rerum Langobardicarum et Italicarum (Hanover, 1878) 398-436.

Gibson, Kelly, The Carolingian world through hagiography, History Compass 13/12 (2015) 630-645.

Giovanni Diacono, Istoria Veneticorum, ed. Luigi Andrea Berto (Bologna, 1999).

Goullet, Monique, Écriture et réécriture hagiographiques: Essai sur les réécritures de Vies de saints dans l'Occident latin médiéval (VIIIe-XIIIe siècle) (Turnhout, 2005).

Granier, Thomas, Conflitti, compromessi e trasferimenti di reliquie nel Mezzogiorno latino del secolo IX, Hagiographica 13 (2006) 33-71.

Granier, Thomas, Lieux de mémoire-lieux de culte à Naples aux Ve-Xe siècles: Saint Janvier, saint Agrippin et le souvenir des évêques, in: Claudio Carozzi, Huguette Taviani-Carozzi (eds.), Faire mémoire: Souvenir et commémoration au Moyen Âge (Aix-en-Provence, 1999) 63-101.

Granier, Thomas, Un miracle accompli par le contact d'une effigie de saint Janvier à Naples au IXe siècle, Revue belge de philologie et d'histoire 75/4 (1997) 957-966.

Granier, Thomas, Saints fondateurs, récits d'origine et légendes apostoliques dans l'Italie méridionale des VIIIe-XIIe siècles, in: Edina Bozóky (ed.), Hagiographie, idéologie et politique au Moyen Âge en Occident (Turnhout, 2012) 165-184.

Grierson, Philip and Mark Blackburn (eds.), Medieval European Coinage 1: The Early Middle Ages (5th-10th Centuries) (Cambridge, 1986).

Historia inventionis ac translationis et miracula Sanctae Trophimenis (BHL 8316-8318), AASS, Iul. II (Paris, 1867) 231-240.

Das »Itinerarium Bernardi monachi«: Edition-Übersetzung-Kommentar, ed. Josef Ackermann, MGH Studien und Texte 50 (Hanover, 2010).

Kislinger, Ewald, La storia di Lipari bizantina riconsiderata, in: Vittorio Gustolisi (ed.), Alla ricerca di Lipari bizantina (Palermo, 2001) 13-21.

La Rocca, Cristina, Le élites, chiese e sepolture familiari tra VIII e IX secolo in Italia settentrionale, in: Philippe Depreux, François Bougard and Regine Le Jan (eds.), Les élites et leurs espaces: Mobilité, Rayonnement, Domination (du VIe au XIe siècle) (Turnhout, 2007) 259-272.

La Rocca, Cristina and Francesco Veronese, Cultures of unanimity in Carolingian councils, in: Serena Ferente, Lovro Kunčević and Miles Pattenden (eds.), Cultures of Voting in Pre-Modern Europe (Abingdon-on-Thames, 2017) 39-57.

Liber de episcopis Mettensibus, ed. Chiara Santarossa (Florence, 2015).

Loré, Vito, Curtis regia e beni dei duchi: Il patrimonio pubblico nel regno longobardo, in: François Bougard and Vito Loré (eds.), Biens publics, biens du roi: Les bases économiques des pouvoirs royaux dans le haut Moyen Âge (Turnhout, 2019) 31-78. 
Loré, Vito, Monasteri, re e duchi: Modelli di relazione fra VIII e X secolo, in: Monachesimi d'Oriente e d'Occidente nell'alto medioevo. Settimane di studio della Fondazione Centro italiano di studi sull'alto medioevo 64 (Spoleto, 2017) 947-984.

Manarini, Edoardo, The translation of St Sylvester's relics from Rome to Nonantola: Itineraries of corpora sacra at the crossroads between devotion and identity in eighth-tenth century Italy, Medieval Worlds 13 (2021) 76-103.

Martin, Jean Marie, Guerre, accords et frontières en Italie méridionale pendant le haut Moyen Âge (Rome, 2005).

McKitterick, Rosamond, Charlemagne: The Formation of a European Identity (Cambridge, 2008).

Nef, Annelise, Reinterpreting the Aghlabids' Sicilian policy (827-910), in: Glaire D. Anderson, Corisande Fenwick and Mariam S. A. Rosser-Owed (eds.), The Aghlabids and their Neighbours: Art and Material Culture in 9th-Century North Africa (Leiden, 2017) 76-87.

Oddy, Andrew W., Analysis of the gold coinage of Beneventum, Numismatic Chronicle 19 (1974) 78-109.

Oldoni, Massimo, Agiografia longobarda tra secolo IX e X: La leggenda di Trofimena, Studi medievali 12/2 (1971) 583-636.

Pactum Sicardi, ed. Jean Marie Martin, Guerre, accords et frontières en Italie méridionale pendant le haut Moyen Âge (Rome, 2005) 185-200.

Passio Helari et Tatiani, ed. Marianna Cerno, in: Emanuela Colombi (ed.), Le passioni dei martiri aquileiesi e istriani 1 (Rome, 2008) 304-320.

Passio Hermachorae et Fortunati, ed. Paolo Chiesa, in: Emanuela Colombi (ed.), Le passioni dei martiri aquileiesi e istriani 1 (Rome, 2008) 171-188.

Passio et translatio Beneventum ss. Felicitatis cum septem filiis (BHL 2855), AASS, Iul. III (Paris, 1867) 14-18.

Pauli Historia Langobardorum, ed. Ludwig Bethmann and Georg Waitz, MGH Scriptores rerum Langobardicarum (Hanover, 1878) 12-187.

Pazienza, Annamaria, Archival documents as narrative: The sources of the Istoria Veneticorum and the plea of Rizana, in: Sauro Gelichi and Stefano Gasparri (eds.), Venice and its Neighbors from the 8th to the 11th Century: Through Renovation and Continuity (Leiden, 2018) 27-50.

Pazienza, Annamaria, Venice beyond Venice: Commercial agreements and Pacta from the origins to Pietro II Orseolo, in: Gelichi Sauro and Stefano Gasparri (eds.), The Age of Affirmation: Venice, the Adriatic and the Hinterland between the 9th and 1oth Centuries I tempi del consolidamento: Venezia, l'Adriatico e l'entroterra tra IX e X secolo (Turnhout, 2018) 147-176.

Pazienza, Annamaria and Francesco Veronese, Pipino e la questione veneziana: Immagine e rappresentazione di un sovrano carolingio, in: Giuseppe Albertoni and Francesco Borri (eds.), Spes Italiae: Il regno di Pipino, i Carolingi e l'Italia (forthcoming).

Peduto, Paolo, Arechi II a Salerno: Continuità e rinnovamento, in: Lucia Sinisi (ed.), Presenze longobarde in Italia meridionale: Il caso della Puglia (Ravenna, 2007) 19-30.

Phelan, Owen M., The Formation of Christian Europe: The Carolingians, Baptism, and the Imperium Christianum (Oxford, 2014).

Picard, Jean-Charles, Le souvenir des évêques: Sépultures, listes épiscopales et culte des évêques en Italie du Nord des origines au Xe siècle (Rome, 1988). 
Pilsworth, Claire L., Vile Scraps: »Booklet« style manuscripts and the transmission and use of the Italian martyr narratives in early medieval Europe, in: Richard Corradini (ed.), Zwischen Niederschrift und Wiederschrift: Hagiographie und Historiographie im Spannungsfeld von Kompendienüberlieferung und Editionstechnik. Forschungen zur Geschichte des Mittelalters 18 (Vienna, 2010) 175-196.

Provesi, Chiara, La terre et la mer: La construction de la mémoire de Venise dans l'Istoria Veneticorum de Jean Diacre, in: Alban Gautier and Lucie Malbos (eds.), Communautés maritimes et insulaires du premier Moyen Âge (Turnhout, 2020) 67-78.

Rando, Daniela, Una Chiesa di frontiera: Le istituzioni ecclesiastiche veneziane nei secoli VIXII (Bologna, 1994).

Reimitz, Helmut, History, Frankish Identity and the Framing of Western Ethnicity, 550-850 (Cambridge, 2015).

Relatio Compendiensis, ed. Courtney L. Booker, The public penance of Louis the Pious: A new edition of the Episcoporum de poenitentia, quam Hludowicus imperator professus est, relatio Compendiensis (833), Viator 39/2 (2008) 1-19: 11-19.

Riché, Paul, Les Carolingiens en quête de sainteté, in: Les fonctions des saints dans le monde occidental (IIIe-XIIIe siècle), Collection de l’École française de Rome 149 (Rome, 1991) 217-224.

Rotili, Marcello, Spazi monastici a Benevento, Hortus artium medievalium 23 (2017) 240-261.

Sangermano, Gerardo, Il ducato di Amalfi, in: Giuseppe Galasso and Rosario Romeo (eds.), Storia del Mezzogiorno 2/1: Il Medioevo (Naples, 1988) 279-321.

Smith, Julia M.H., Old saints, new cults: Roman martyrs in Carolingian Francia, in: Julia M. H. Smith (ed.), Early Medieval Rome and the Christian West: Essays in Honour of Donald Bullough (Leiden, 2000) 317-334.

Sot, Michel, Service de l'empire et culte des saints dans la correspondance d'Éginhard, in: Bruno Dumézil and Laurent Vissière (eds.), Épistolaire politique 1: Gouverner par les lettres (Paris, 2014) 91-105.

Sotinel, Claire, The Three Chapters and the transformations of Italy, in: Celia Chazelle and Catherine Cubitt (eds.), The Crisis of the Oikoumene: The Three Chapters and the Failed Quest for Unity in the Sixth-Century Mediterranean (Turnhout, 2007) 85-120.

Ss. Ilario e Benedetto e S. Gregorio, ed. Luigi Lanfranchi and Bruna Strina (Venice, 1965).

Štih, Peter, Imperial politics and its regional consequences: Istria between Byzantium and the Franks 788-812, in: Mladen Ančić, Jonathan Shepard and Trpimir Vedriš (eds.), Imperial Spheres in the Adriatic: Byzantium, the Carolingians and the Treaty of Aachen (812) (London, 2018) 57-72.

Taviani-Carozzi, Huguette, La principauté lombarde de Salerne (IXe-XIe): Pouvoir et societé en Italie lombarde méridionale (Rome, 1991).

Thomas, Aurélie, Jeux lombards: Alliances, parenté et politique en Italie méridionale de la fin du VIIIe siècle à la conquête normande (Rome, 2016).

Tomea, Paolo, Intorno a Santa Giulia: Le traslazioni e le »rapine« dei corpi santi nel regno longobardo (Austria e Neustria), in: Giancarlo Andenna (ed.), Culto e storia di Santa Giulia (Brescia, 2001) 29-52.

Translatio S. Bartholomaei Liparim et inde Beneventum, ed. Stefano Borgia, Memorie istoriche della pontificia città di Benevento 1 (Rome, 1763) 333-348.

Translatio corporis sancti Bartholomei apostoli Beneventum et miracula, ed. Ulla Westerbergh, Anastasius Bibliothecarius sermo Theodori Studitae de sancto Bartholomeo apostolo (Stockholm, 1963) 8-17. 
Translatio Marci evangelistae Venetias, ed. Emanuela Colombi, "Translatio Marci evangelistae Venetias«, BHL 5283-5284, Hagiographica 17 (2010) 73-129: 112-129.

Translatio et miracula SS. Petri et Marcellini, ed. Georg Waitz, MGH SS 15/1 (Hanover, 1887) 238-264.

Translatio sanctorum Ianuarii, Festi et Desiderii, AASS Sept. VI (Paris, 1867) 888-890.

Veronese, Francesco, Saint Marc entre Venise et Reichenau: Les reliques de l'évangéliste comme objet et enjeu de compétition (IXe-Xe siècles), in: Philippe Depreux, François Bougard and Régine Le Jan (eds.), Compétition et sacré au haut Moyen Âge: Entre médiation et exclusion (Turnhout, 2015) 295-312.

Veronese, Francesco, Tra rispetto delle leggi e furti notturni: Narrazioni di mobilità delle reliquie nelle translationes carolinge, Mélanges de l'École Française de Rome - Moyen Âge 132/2 (2020). Accessed on 16 February 2021: journals.openedition.org/mefrm/8396.

Vocino, Giorgia, Caccia al discepolo: Tradizioni apostoliche nella produzione agiografica dell'Italia settentrionale (VI-XI secolo), in: Cristina La Rocca and Piero Majocchi (eds.), Urban Identities in Northern Italy, 800-1100 Ca. (Turnhout, 2015) 357-402.

Vocino, Giorgia, Les saints en lice: Hagiographie et reliques entre Cividale et Grado à l'époque carolingienne, in: Philippe Depreux, François Bougard and Régine Le Jan (eds.), Compétition et sacré au Haut Moyen Âge: Entre médiation et exclusion (Turnhout, 2015) 273-293.

Vocino, Giorgia, Le traslazioni di reliquie in età carolingia (fine VIII-IX secolo): Uno studio comparativo, Rivista di storia e letteratura religiosa 44 (2008) 207-255.

Vocino, Giorgia, Under the aegis of the saints: Hagiography and power in early Carolingian northern Italy, Early Medieval Europe 22/1 (2014) 26-52.

Vuolo, Antonio, Agiografica beneventana, in: Giancarlo Andenna and Giorgio Picasso (eds.) Longobardia e longobardi nell'Italia meridionale: Le istituzioni ecclesiastiche (Milan, 1996) 199-237.

West, Geoffrey V.B., Communities and pacta in early medieval Italy: Jurisdiction, regulatory authority and dispute avoidance, Early Medieval Europe 18/4 (2010) 367-393.

Westerbergh, Ulla, Anastasius Bibliothecarius sermo Theodori Studitae de sancto Bartholomeo apostolo (Stockholm, 1963).

West-Harling, Veronica, Rome, Ravenna, and Venice, 750-10oo: Byzantine Heritage, Imperial Present, and the Construction of City Identity (Oxford, 2020).

Wickham, Chris, Considerazioni conclusive, in: Riccardo Francovich and Ghislaine Noyé (eds.), La storia dell'alto medioevo italiano (VI-X secolo) alla luce dell'archeologia (Florence, 1994) 741-759.

Wood, Ian N., Giovardi, MS Verolensis 1, Arichis and Mercurius, in: Richard Corradini (ed.), Zwischen Niederschrift und Wiederschrift: Hagiographie und Historiographie im Spannungsfeld von Kompendienüberlieferung und Editionstechnik. Forschungen zur Geschichte des Mittelalters 18 (Vienna, 2010) 67-78.

Wood, Susan, The Proprietary Church in the Medieval West (Oxford, 2006).

Zornetta, Giulia, Italia meridionale longobarda: Competizione, conflitto e potere politico a Benevento (secoli VIII-IX) (Rome, 2020).

Zornetta, Giulia, Il monastero femminile di Santa Sofia di Benevento: Ambizioni e limiti di un progetto politico e familiare nell'Italia meridionale longobarda (secc. VIII-IX), Reti medievali 20/1 (2019) 541-566. 